Acta vet. scand. $1968,9,350-363$.

From the National Veterinary Institute, Stockholm, Sweden.

\title{
STUDIES ON ASPERGILLUS FUMIGATUS; STABILITY OF HAEMOLYSIN AND TOXIN IN CRUDE FILTRATE
}

\author{
By \\ Lars Rutqvist
}

Mycelial filtrates of Aspergillus fumigatus (AF) have proved to have toxic and haemolytic properties. When administered parenterally, they produce, as the most conspicuous pathoanatomical lesions, renal damage in several animal species (Henrici 1939, Tilden et al. 1961, 1963, Rutqvist \& Persson 1966). In pigs, perirenal edema was, in addition, consistently observed (Rutquist \& Persson).

According to Freeman (1960), parenteral administration of AF toxin (prepared by Tilden et al. 1961) caused metabolic disturbances in female rats, in the form of hypercitricaemia and hypercalcaemia.

In in vitro experiments with AF toxin fractionated on DEAEcellulose by Wynston \& Tilden (1963), Lee et al. (1965) observed that a low toxin concentration stimulated respiration in renal tissue, whereas a high concentration impaired respiration and caused uncoupling of the oxidative phosphorylation.

It was shown in a previous investigation that, despite high toxicity on parenteral administration, no clinical symptoms or patho-anatomical changes appeared in mice, chicks or pigs when AF filtrates were given orally (Rutquist \& Persson). Consequently, the stability of the toxin and haemolysin in AF filtrates should be of interest. An account is given in this paper of a study of this property with respect to heat inactivation at different $\mathrm{pH}$ values. Studies were also made of the formation of toxoid under 
the influence of formalin, as well as of the effect of various metals and potential enzyme inhibitors on, in the first place, the haemolysin.

\section{MATERIAL AND METHODS}

Apart from minor modifications, the methods were the same, in relevant parts, as those described earlier (Rutqvist 1965).

Strains. The AF strain 6869 was chosen for the inactivation experiments, and the AF strain 938 for the neutralization tests (Rutqvist).

Media. The strains were maintained at room temperature on agar slants of Sabouraud's agar, and were recultured once a month. Cultures for production of mycelial filtrates were made in fluid medium, consisting of proteose-peptone Difco $(1.5 \%)$, yeast extract Difco $(0.5 \%)$, dextrose $(3 \%)$ and $\mathrm{NaCl}(0.5 \%)$ in distilled water, $\mathrm{pH}$ 7.2.

Filtrate preparation. Strain cultures grown for 7 days at $20^{\circ} \mathrm{C}$ on Sabouraud's agar in agar slants were suspended with $10 \mathrm{ml}$ of proteose-peptone broth per tube, and $1 \mathrm{ml}$ was transferred to $300 \mathrm{ml}$ of fluid medium in Roux flasks. The mycelial mats, which after 3 days' incubation at $37^{\circ} \mathrm{C}$ had grown on the surface of the medium, were washed on harvesting with sterile, distilled water, dried on filter paper and kept at $-20^{\circ} \mathrm{C}$ for $2-4$ days.

To $100 \mathrm{~g}$ of frozen mycelial material was added $75 \mathrm{ml}$ of sterile distilled water, and the mixture was homogenized in a mixer at 11,000 r. p. m. The homogenate was stored at $4^{\circ} \mathrm{C}$ for 5 days and centrifuged at $2,500 \times \mathrm{g}$ for 20 min., after which the supernatant was filtered through a Seitz EK filter. The filtrate was frozen, and stored at $-20^{\circ} \mathrm{C}$.

Two filtrates prepared from strain 6869 were used for the experiments. In one of them, used in heat inactivation at various $\mathrm{pH}$, the titre for $\mathrm{LD}_{50}$ in mice (denoted here as $\mathrm{MLD}_{50}$ ) and the haemolytic unit (HU) were $10^{-2.6}$ and $2^{-10} \mathrm{ml}$, respectively. In the other preparation from strain 6869 , used for toxoid preparation, and in the filtrate preparation from strain 938 , the corresponding titres were of the same size in both filtrates, and amounted to $10^{-2.2}$ and $2^{-9} \mathrm{ml}$, respectively. The titres comprised the mean of $2-6$ determinations per filtrate. The two filtrates from strain 6869 had a $\mathrm{pH}$ of 6.7 . The $\mathrm{pH}$ of the strain 938 filtrate was 7.0.

Toxicity. The $\mathrm{MLD}_{50}$ titre was calculated by Kärber's formula. Groups of 10 mice belonging to the NMRI strain (Naval Medical Research Institute, Bethesda, Md., USA), weighing 16-18 g, were inoculated intraperitoneally with each of a series of 10-fold dilutions of the filtrate. The dilution fluid was $0.9 \% \mathrm{NaCl}$ solution. The volume of the inoculum was $0.5 \mathrm{ml}$ per mouse. The mice were kept under observation for 10 days. 
Haemolytic activity. Sheep erythrocytes in Alsever's fluid, kept at $4^{\circ} \mathrm{C}$ for maximally 4 days, were washed with $1 / 10 \mathrm{M}$ veronal buffer, $\mathrm{pH} \mathrm{7,} \mathrm{and} \mathrm{diluted} \mathrm{in} \mathrm{the} \mathrm{buffer} \mathrm{to} \mathrm{a} 2 \%$ suspension. Of this suspension, $0.5 \mathrm{ml}$ was added to $0.5 \mathrm{ml}$ of the strain filtrate in 2-fold serial dilutions with $0.9 \% \mathrm{NaCl}$. The haemolytic activity was read after incubation for $30 \mathrm{~min}$. at $37^{\circ} \mathrm{C}$ and $90 \mathrm{~min}$. at $20^{\circ} \mathrm{C}$. The smallest quantity of filtrate producing complete haemolysis was taken as the titre of haemolytic activity, and expressed as 1 haemolytic unit (HU).

Immune serum. Antiserum to strain 938 filtrate was obtained from rabbits which, at 3-4-day intervals, had been injected intravenously with a filtrate containing $5,10,20,40,80$ and $120 \mathrm{MLD}_{50}$ toxin. The serum was collected 10 days after the last injection.

Strain 6869 filtrate antiserum was prepared by using formalininactivated filtrate as antigen. Inactivation took place by incubation at $37^{\circ} \mathrm{C}$ for 5 days of a formalin-filtrate mixture with a $6 \times 10^{-2} \mathrm{M}$ concentration of formalin. Five $\mathrm{ml}$ of formalin-inactivated antigen was mixed with $5 \mathrm{ml}$ of Bacto adjuvant complete Freund, Difco. Five $\mathrm{ml}$ of the mixture was inoculated subcutaneously in rabbits on two occasions, at an interval of 14 days. The serum was collected 14 days after the last injection.

After heating at $56^{\circ} \mathrm{C}$ for $30 \mathrm{~min}$. and addition of merthiolate $(1: 10,000)$, the sera were stored at $4^{\circ} \mathrm{C}$.

Normal serum. Normal serum was obtained from a healthy rabbit, and stored at $4{ }^{\circ} \mathrm{C}$ after heating at $56^{\circ} \mathrm{C}$ for $30 \mathrm{~min}$., and addition of merthiolate $(1: 10,000)$.

Inhibition of haemolysis. Serial dilutions $1: 20$, $1: 40$, etc. of immune sera and normal serum with $0.9 \% \mathrm{NaCl}$ solution in volumes of $0.5 \mathrm{ml}$ were mixed with $0.5 \mathrm{ml}$ of filtrate dilution containing $4 \mathrm{HU}$. The mixture was allowed to stand for $1 \mathrm{hr}$. at $20^{\circ} \mathrm{C}$, after which $0.3 \mathrm{ml}$ of erythrocyte suspension was added. The results were read after incubation for $30 \mathrm{~min}$. at $37^{\circ} \mathrm{C}$ and for $90 \mathrm{~min}$. at $20^{\circ} \mathrm{C}$.

Neutralization experiments. To each dilution of immune sera and normal serum diluted 2-fold with $0.9 \% \mathrm{NaCl}$ was added filtrate from strain 938 diluted with $0.9 \% \mathrm{NaCl}$ so that $0.6 \mathrm{ml}$ of the filtrate-serum mixture contained $3.5 \mathrm{MLD}_{50}$ toxin. The proportions between filtrate and serum dilutions were such that each of 10 mice per serum dilution was inoculated intraperitoneally with $0.5 \mathrm{ml}$ of serum dilution and $0.1 \mathrm{ml}$ of filtrate dilution. Before inoculation was performed, the filtrate-serum mixtures had been kept for $1 \mathrm{hr}$. at $20^{\circ} \mathrm{C}$ and for $20 \mathrm{hrs}$. at $4^{\circ} \mathrm{C}$. The mice were kept under observation for 10 days.

pH determination. All $\mathrm{pH}$ determinations were made with a glass electrode, using a type $28 \mathrm{pH}$ meter (Radiometer, Copenhagen, Denmark).

Chemical substances. All chemicals used in the experiments were of analytical grade. 


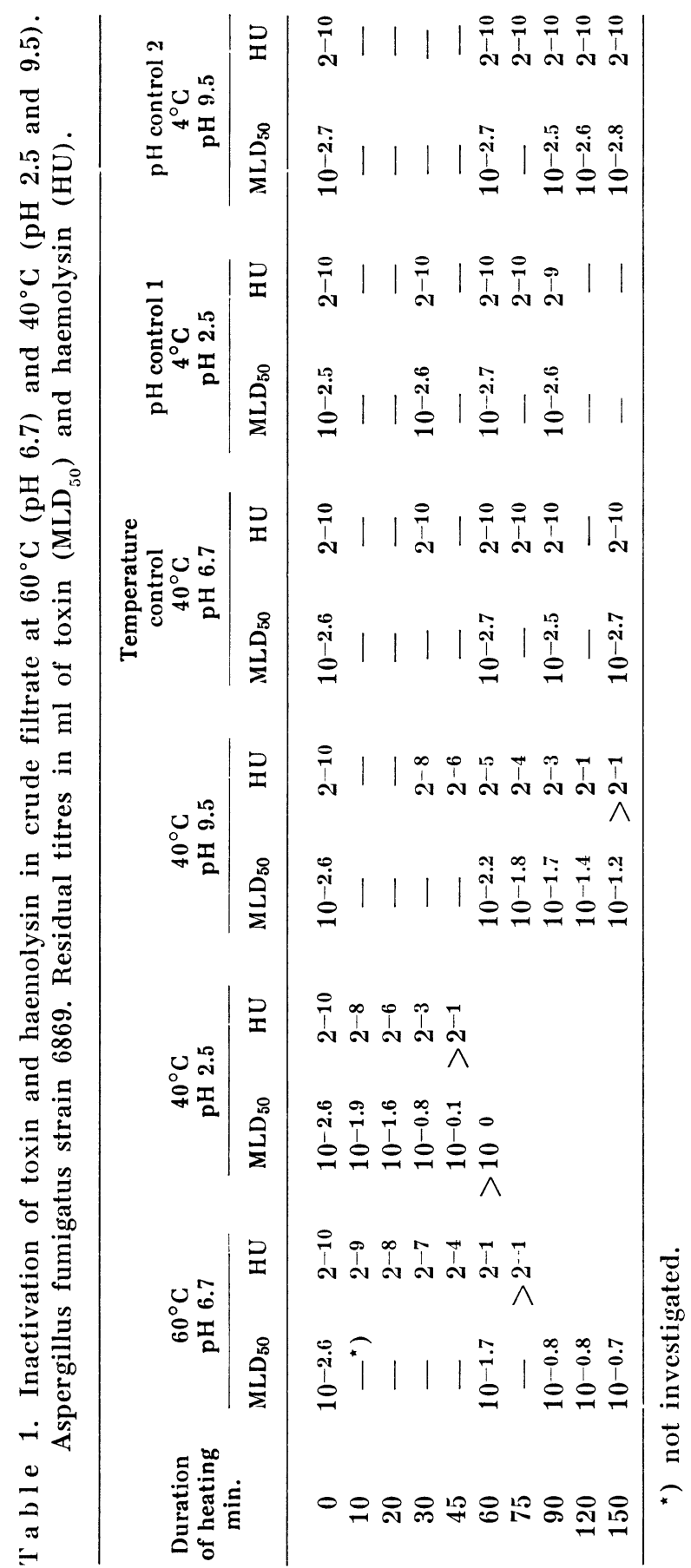




\section{EXPERIMENTAL AND RESULTS}

\section{Influence of heat on toxin and haemolysin at various $\mathrm{pH}$}

The stability of the haemolysin and toxin in a crude filtrate of strain 6869 was studied after heating for $10-150 \mathrm{~min}$. This was done both at $60^{\circ} \mathrm{C}$ at a $\mathrm{pH}$ of 6.7 , and at $40^{\circ} \mathrm{C}$ at $\mathrm{pH}$ values of 2.5 and 9.5, respectively. The temperatures and $\mathrm{pH}$ values of 2.5 and 9.5 were chosen on the basis of results of preliminary experiments. These showed that an increase in the stated temperatures of $5^{\circ} \mathrm{C}$ at the different $\mathrm{pH}$ values produced a disappearance of haemolytic activity within $30 \mathrm{~min}$., whereas a decrease of $5^{\circ} \mathrm{C}$ resulted in persisting haemolytic activity after $2 \mathrm{hrs}$. heat treatment. In filtrates heated at $40^{\circ} \mathrm{C}$, a reduction in $\mathrm{pH}$ below 2.5 and a rise above 9.5 by $0.5 \mathrm{pH}$ caused haemolytic activity to disappear within 30 min. When, on the other hand, these $\mathrm{pH}$ values were raised and lowered, respectively, by $0.5 \mathrm{pH}$ unit, the activity persisted after 2 hrs. heating.

The $\mathrm{pH}$ of the filtrates was adjusted with $2 \mathrm{~N}-\mathrm{HCl}$ and 2 $\mathrm{N}-\mathrm{NaOH}$. Heating was done in a water bath, the filtrate being heated in 5-ml portions in thin-walled, stoppered glass tubes. Immediately after the tubes had been removed from the water bath, they were cooled under running cold water, and the $\mathrm{pH}$ was adjusted to 6.7. They were then kept at $4^{\circ} \mathrm{C}$ until the activity was determined, which generally took place within 2 hrs.

The results of the inactivation experiments can be inferred from Table 1. In Figs. $1-3$, the decrease in the titres of the toxic and the haemolytic activity is plotted against time.

The inactivation curves for toxin and haemolysin showed a wide divergence, with better stability of the toxin when the filtrate was heated at $60^{\circ} \mathrm{C}$ with a pH of 6.7 and at $40^{\circ} \mathrm{C}$ with a pH of 9.5 (Figs. 1 and 3 ). Heating at $40^{\circ} \mathrm{C}$ and $\mathrm{pH} 2.5$ resulted, as can be seen in Table 1 , in rapid inactivation of both haemolysin and toxin. In this case, it seems possible for both inactivation curves to be represented by the same straight line (Fig. 2). Merely heating of the filtrate at $40^{\circ} \mathrm{C}$ at a $\mathrm{pH}$ of 6.7 , as well as storing in the refrigerator after adjusting the $\mathrm{pH}$ to 2.5 and 9.5, respectively, with neutralization to $\mathrm{pH} 6.7$ after the times given in Table 1, seemed to have no effect on the activity of either the haemolysin or the toxin (Table 1 ). 


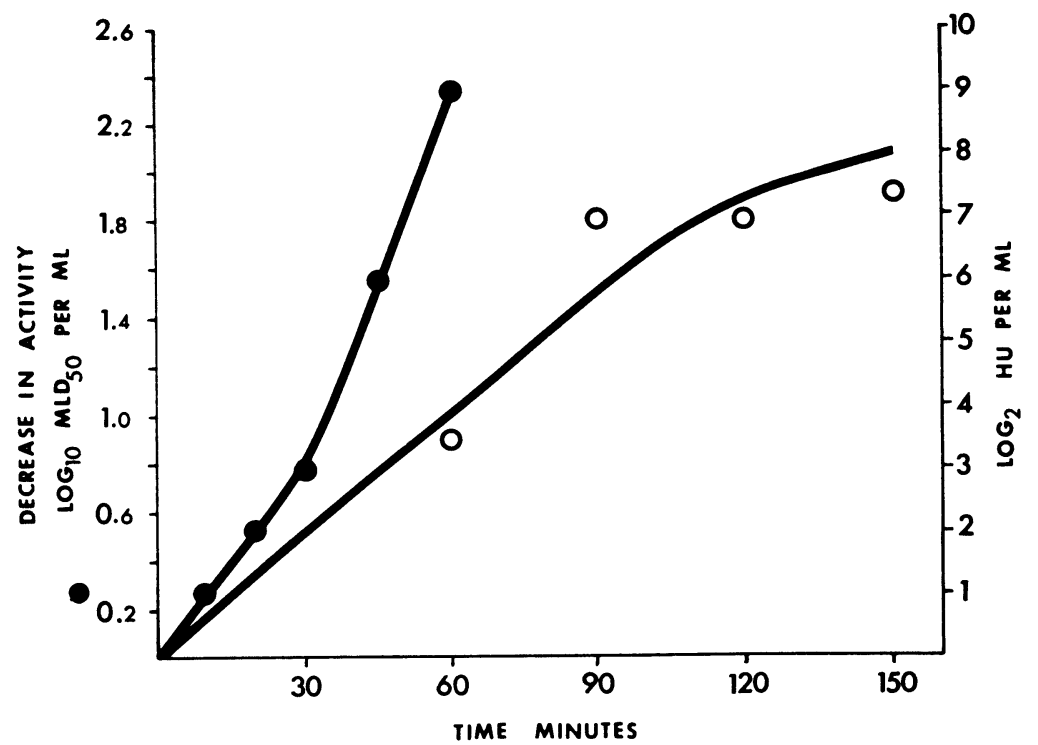

$\mathrm{Fi}$ i u r e 1. Inactivation at $60^{\circ} \mathrm{C}$ and $\mathrm{pH} 6.7$ of haemolysin and toxin. Aspergillus fumigatus strain 6869 .
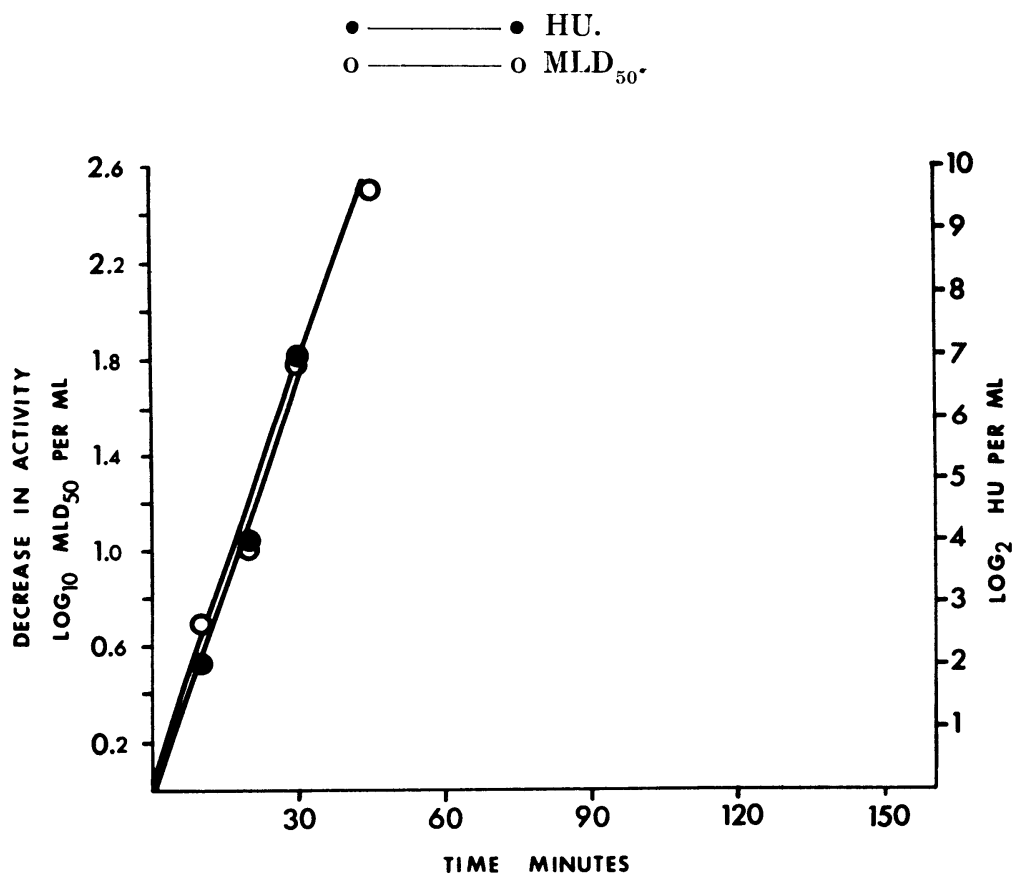

$\mathrm{F} \mathrm{i} \mathrm{g} \mathrm{u} \mathrm{r} \mathrm{e} \mathrm{2.} \mathrm{Inactivation} \mathrm{at} 40^{\circ} \mathrm{C}$ and $\mathrm{pH} 2.5$ of haemolysin and toxin. Aspergillus fumigatus strain 6869 .

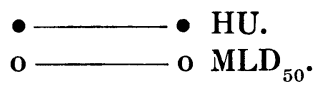




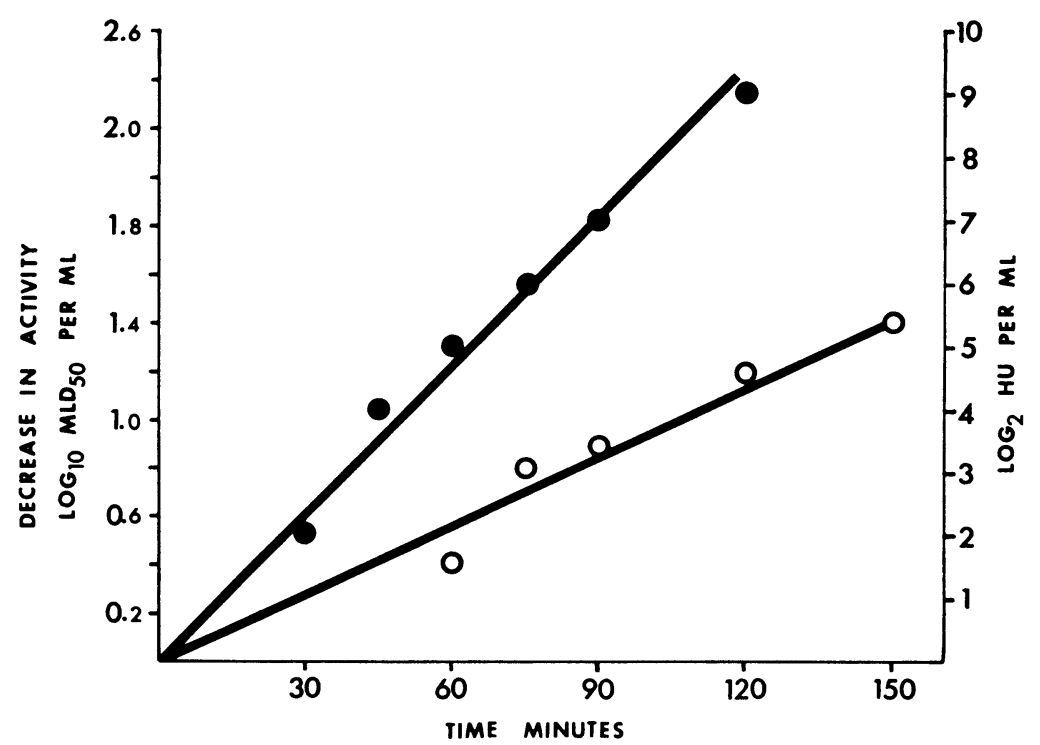

$\mathrm{F} \mathrm{i} \mathrm{g} \mathrm{u} \mathrm{r} \mathrm{e} \mathrm{3.} \mathrm{Inactiviation} \mathrm{at} 40^{\circ} \mathrm{C}$ and $\mathrm{pH} 9.5$ of haemolysin and toxin. Aspergillus fumigatus strain 6869 .
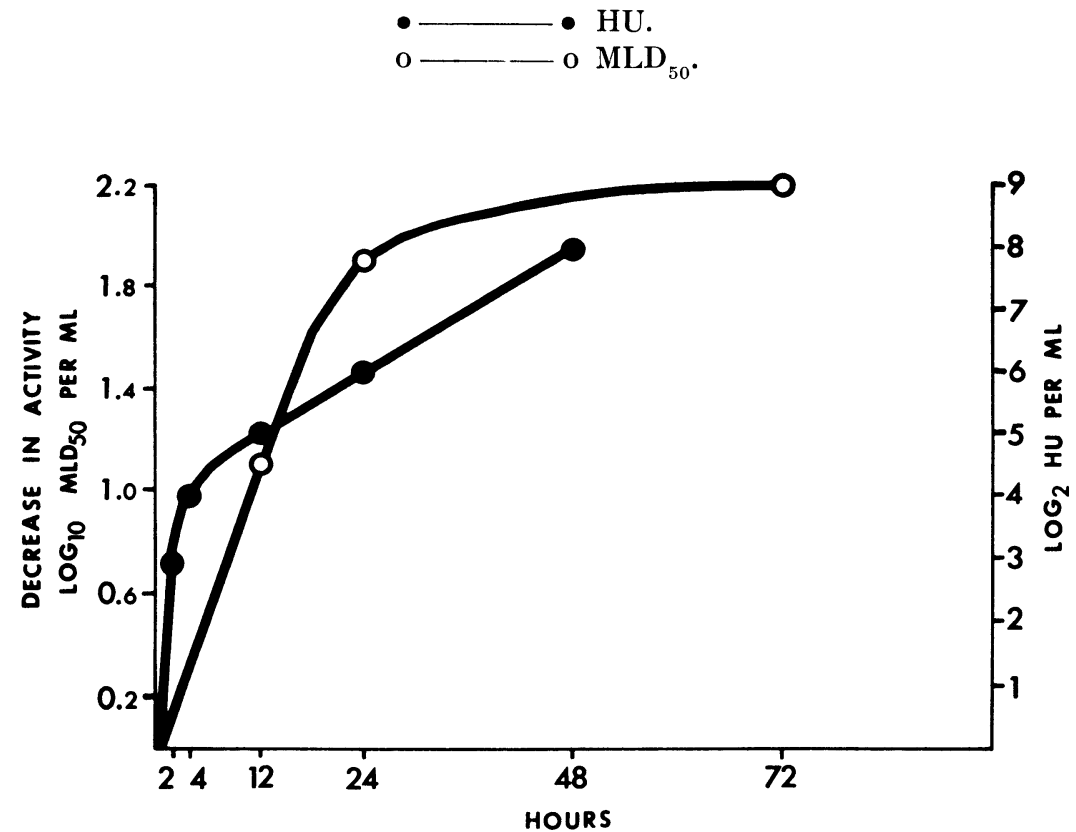

Figure 4. Formalin inactivation at $37^{\circ} \mathrm{C}$ and $\mathrm{pH} 6.7$ of haemolysin and toxin. Aspergillus fumigatus strain 6869.

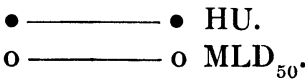


Inactivation of toxin and haemolysin by formalin

In order to investigate if toxin and haemolysin could be transformed into toxoids, experiments with formalin treatment and neutralization tests were performed.

T a b l e 2. Inactivation at $37^{\circ} \mathrm{C}(\mathrm{pH}$ 6.7) of toxin and haemolysin in crude filtrate with addition of formalin to a final concentration of $6 \times 10^{-2} \mathrm{M}$. Aspergillus fumigatus strain 6869. Residual titres in $\mathrm{ml}$ of toxin $\left(M L D_{50}\right)$ and haemolysin (HU).

\begin{tabular}{|c|c|c|c|c|c|c|c|c|c|}
\hline \multirow{2}{*}{ Strain } & \multirow{2}{*}{ Activity } & \multicolumn{8}{|c|}{ Duration of formalin treatment, hours } \\
\hline & & 0 & 2 & 4 & 12 & 24 & 48 & 72 & 96 \\
\hline 6869 & $\begin{array}{l}\text { MLD }_{50} \\
\mathrm{HU}\end{array}$ & $\begin{array}{c}10^{-2.2} \\
2^{-9}\end{array}$ & $\left.\overline{2}^{\star}\right)$ & $\overline{2^{-5}}$ & $\begin{array}{c}10^{-1.1} \\
2^{-4}\end{array}$ & $\begin{array}{c}10-0.3 \\
2-3\end{array}$ & $\overline{2^{-1}}$ & $\begin{array}{c}10^{0} \\
>2^{-1}\end{array}$ & $>10^{0}$ \\
\hline $\begin{array}{l}\text { Tempera- } \\
\text { ture } \\
\text { Control }\end{array}$ & $\begin{array}{l}\text { MLD }_{50} \\
H U\end{array}$ & $\begin{array}{c}10^{-2.2} \\
2^{-9}\end{array}$ & - & - & $\overline{2-9}$ & - & - & - & $\begin{array}{c}10-2.3 \\
2-8\end{array}$ \\
\hline
\end{tabular}

*) not investigated.

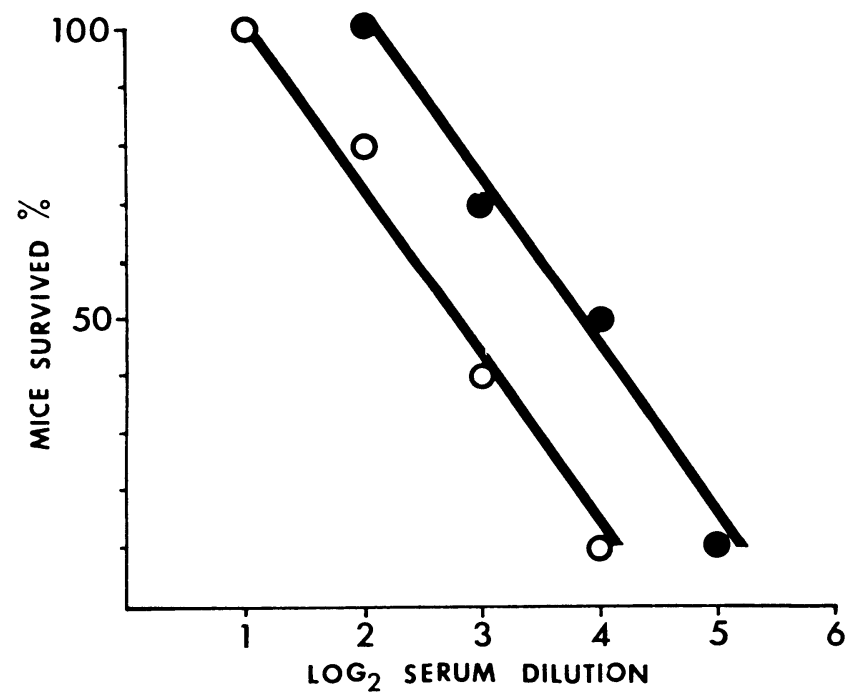

Figure 5. Neutralizing effects of immune sera prepared against formalinized (strain 6869) and non-formalinized (strain 938) antigens

from Aspergillus fumigatus.

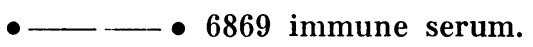

o- o 938 immune serum. 
In filtrate with $\mathrm{pH} 6.7$ and a $6 \times 10^{-2} \mathrm{M}$ concentration of formalin, incubated in a thermostat at $37^{\circ} \mathrm{C}$, haemolytic activity could not be demonstrated after 72 hrs. incubation, and after 96 hrs. no toxic activity was to be found (Table 2). The greater part of the activity of both haemolysin and toxin disappeared during the first 24 hrs. of incubation. In Fig. 4, where the titres of decrease in haemolysin and toxin activities are plotted against time, the resulting inactivation curves are shown.

\section{Neutralization of toxin and haemolysin by antisera}

It is evident from Fig. 5 that immune sera against formalinized (strain 6869) and non-formalinized (strain 938) filtrates had a toxin-neutralizing effect. A better neutralizing effect could be observed in immune serum prepared against formalinized filtrate to which adjuvant had been added.

Normal serum in 1:2 dilution had no toxin-neutralizing effect.

Both immune sera inhibited haemolysis in a dilution of $1: 40$, whereas normal serum in a dilution of 1:20 had no inhibitory effect on the haemolytic activity.

\section{Influence of some metal ions and potential enzyme inhibitors} on haemolysin in crude filtrate

In work with filtrate preparations preserved with merthiolate and stored at $4^{\circ} \mathrm{C}$, it had been observed that the haemolytic activity gradually decreased and after some time disappeared. The toxic activity, however, was apparently not influenced.

The disappearance of haemolytic activity caused by merthiolate made it of interest to investigate the influence on the haemolysin of other mercury compounds and some common heavy metals and potential enzyme inhibitors.

The chemical substances listed in Table 3 were allowed to act on the filtrate for $60 \mathrm{~min}$. in a thermostat at $37^{\circ} \mathrm{C}$, after which the haemolytic activity was determined. The results are given in Table 3.

No haemolytic activity was demonstrated in filtrates with a $10^{-2} \mathrm{M}$ and $10^{-3} \mathrm{M}$ concentration of mercury. A $10^{-4} \mathrm{M}$ concentration of $\mathrm{Hg}$ also had a marked immediate effect, and the haemolysin was completely inactivated after $60 \mathrm{~min}$. incubation at $37^{\circ} \mathrm{C}$. With an $\mathrm{Hg}$ content of $10^{-5} \mathrm{M}$, full haemolytic activity 
T a ble 3. Influence of some metal ions and potential enzyme inhibitors on haemolysin in crude filtrate. Aspergillus fumigatus strain 6869 .

\begin{tabular}{|c|c|c|c|c|}
\hline \multirow[t]{2}{*}{ Substance } & \multirow[t]{2}{*}{ Molarity } & \multirow[t]{2}{*}{$\mathrm{pH}$} & \multicolumn{2}{|c|}{$\begin{array}{l}\text { Haemolysin (HU) titre in } \mathrm{ml} \\
\text { after incubation at } 37^{\circ} \mathrm{C}\end{array}$} \\
\hline & & & 0 min. & $60 \mathrm{~min}$. \\
\hline Filtrate & & 6.7 & $2^{-9}$ & $2^{-9}$ \\
\hline $\left.\mathrm{Zn}^{++1}\right)$ & $10^{-2}$ & 5.8 & & $2^{-9}$ \\
\hline $\mathrm{Cu}^{++}$ & $10^{-2}$ & 5.0 & & $2^{-9}$ \\
\hline $\mathrm{Co}^{++}$ & $10^{-2}$ & 6.3 & & $2^{-9}$ \\
\hline $\mathrm{Fe}^{++}$ & $10^{-2}$ & 6.2 & $2^{-9}$ & $2^{-8}$ \\
\hline $\mathrm{Ca}^{++}$ & $10^{-2}$ & 6.7 & & $2^{-9}$ \\
\hline $\mathrm{Hg}^{++}$ & $10^{-2}$ & 5.9 & $>2^{-1}$ & \\
\hline , & $10^{-3}$ & 6.7 & $>2^{-1}$ & \\
\hline , & $10^{-4}$ & 6.7 & $2^{-2}$ & $>2^{-1}$ \\
\hline 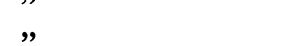 & $10^{-5}$ & 6.7 & & $2^{-9}$ \\
\hline $\left.\mathrm{EDTA}^{2}\right)$ & $10^{-2}$ & 6.3 & & $2^{-9}$ \\
\hline Potassium cyanide & $10^{-2}$ & 7.8 & & $2^{-9}$ \\
\hline Iodoacetic acid & $10^{-2}$ & 6.3 & & $2^{-9}$ \\
\hline L-cysteine & $10^{-2}$ & 5.7 & & $2^{-9}$ \\
\hline Glutathione & $10^{-2}$ & 5.8 & & $2^{-9}$ \\
\hline
\end{tabular}

1) The metals were solutions of $\mathrm{ZnSO}_{4}, \mathrm{CuSO}_{4}, \mathrm{CoCl}_{2}, \mathrm{FeSO}_{4}, \mathrm{CaCl}_{2}$ and $\mathrm{HgCl}_{2}$.

2) Disodium salt of ethylene diamine tetraacetic acid.

was noted. Inactivation of the haemolysin was demonstrable directly after the addition of mercury to the filtrate.

The other substances tested produced no definite change in the haemolytic activity.

\section{Reactivation of mercury-inactivated haemolysin}

L-cysteine or glutathione to a final concentration of $2.5 \times 10^{-3}$, $5 \times 10^{-3}$ and $10^{-2} \mathrm{M}$ was added to filtrates with a $10^{-3} \mathrm{M}$ final concentration of mercury chloride and p-chloromercuribenzoate, respectively. Reactivation of the mercury-inactivated haemolysin was then demonstrable (Table 4). Reactivation was complete in filtrate mixtures with a $10^{-2} \mathrm{M}$ final concentration of L-cysteine or glutathione. 
T a b l e 4. Influence of L-cysteine and glutathione on the haemolysininhibiting effect of mercury compounds. Aspergillus fumigatus strain 6869.

\begin{tabular}{|c|c|c|c|c|c|c|c|c|c|}
\hline \multirow{3}{*}{ Inhibitor } & \multirow{3}{*}{ Molarity } & \multicolumn{8}{|c|}{ Haemolysin (HU) titre in ml } \\
\hline & & \multicolumn{4}{|c|}{$\begin{array}{l}\text { L-cysteine } \\
\text { molarity }\end{array}$} & \multicolumn{4}{|c|}{$\begin{array}{l}\text { Glutathione } \\
\text { molarity }\end{array}$} \\
\hline & & 0 & $2.5 \times 10^{-3}$ & $5 \times 10^{-3}$ & $10^{-2}$ & 0 & $2.5 \times 10^{-3}$ & $5 \times 10^{-3}$ & $10^{-2}$ \\
\hline None & & $2^{-9}$ & & & & $2^{-9}$ & & & \\
\hline Mercury chloride & $10^{-3}$ & $>2^{-1}$ & $>2^{-1}$ & $2^{-7}$ & $2^{-9}$ & $>2^{-1}$ & $2^{-6}$ & $2^{-8}$ & $2^{-9}$ \\
\hline $\begin{array}{l}\text { p-Chloromercuri- } \\
\text { benzoate }^{\star} \text { ) }\end{array}$ & $10^{-3}$ & $>2^{-1}$ & $>2^{-1}$ & $2^{-4}$ & $2^{-9}$ & $>2^{-1}$ & $2^{-5}$ & $2^{-8}$ & $2^{-9}$ \\
\hline
\end{tabular}

*) Sodium salt of p-chloromercuribenzoic acid.

Toxic activity in mercury-treated filtrate

Addition of p-chloromercuribenzoate to a final concentration of $10^{-3} \mathrm{M}$ to $\mathrm{AF}$ filtrate with $\mathrm{pH} 6.7$ appeared to have no definite effect on the toxic activity of the filtrate after keeping the filtrate-mercury mixture for $1 \mathrm{hr}$. at $37^{\circ} \mathrm{C}$, and subsequent storage for 7 days at $4^{\circ} \mathrm{C}$. After storage, the haemolysin was completely reactivated on addition of L-cysteine to a final concentration of $10^{-2} \mathrm{M}$ (Table 5 ).

T a b l e 5. Haemolytic and toxic activity and haemolysin-reactivating ability of L-cysteine in mercury-treated filtrate stored at $4^{\circ} \mathrm{C}$. Aspergillus fumigatus strain 6869 .

\begin{tabular}{|c|c|c|c|c|c|}
\hline \multirow[t]{2}{*}{ Inhibitor } & \multirow[t]{2}{*}{ Reactivator } & \multicolumn{2}{|c|}{$\begin{array}{c}\text { Haemolysin }(\mathrm{HU}) \\
\text { titre in ml } \\
\text { days }\end{array}$} & \multicolumn{2}{|c|}{$\begin{array}{l}\text { Toxin }\left(M L D_{50}\right) \\
\text { titre in ml } \\
\text { days }\end{array}$} \\
\hline & & 0 & 7 & 0 & 7 \\
\hline None & None & $2^{-9}$ & & $10^{-2.2}$ & \\
\hline $\begin{array}{l}\text { p-Chloromer- } \\
\text { curibenzoate } \\
10^{-3 M}\end{array}$ & None & $>2^{-1}$ & $>2^{-1}$ & $10^{-2.3}$ & $10^{-2.1}$ \\
\hline ” & $\begin{array}{l}\text { L-cysteine } \\
10^{-2} \mathrm{M}\end{array}$ & $2^{-9}$ & $2^{-9}$ & & \\
\hline
\end{tabular}




\section{DISCUSSION}

A distinct difference was present between the stability of the haemolysin and that of the toxin, the toxin being the more stable. This was demonstrated when the filtrate with a $\mathrm{pH}$ of 6.7 was heated at $60^{\circ} \mathrm{C}$, and when the filtrate with a $\mathrm{pH}$ of 9.5 was heated at $40^{\circ} \mathrm{C}$. This finding is in agreement with that of Tilden et al. (1961, 1963), and would indicate that the haemolysin and the toxin are different principles. Although Wynston \& Tilden (1963), using chromatography, could not completely separate haemolysin and toxin, they found the greatest haemolytic and toxic activity in different fractions. The dermo-necrotic effect of the AF filtrate in the rabbit proved to be bound to the haemolysin (Tilden et al. 1963).

Rapid inactivation of both haemolysin and toxin was obtained by a $\mathrm{pH}$ of 2.5 at $40^{\circ} \mathrm{C}$. This suggests that gastric juice may have an inactivating effect on the toxin and may explain the absence of a toxic action of the filtrate when given orally, despite its high toxic activity when administered parenterally (Rutquist \& Persson 1966).

Immediate blocking of the activity of the haemolysin by mercury compounds, as well as the reactivating effect of thiol compounds, are of considerable interest. Like pneumococcal haemolysin (Shwachman et al. 1934) and the haemolysin from cobra venom $(D e 1940 \mathrm{a}, \mathrm{b})$, the AF haemolysin shows in this respect a striking parallelism with several enzymes whose effect is considered to depend on active sulphydryl groups. With various mercury compounds they can form mercaptides which are, however, easily reversible under the action of thiols with greater affinity to the inhibiting substance (Barron 1951, Boyer 1959).

\section{REFERENCES}

Barron, E. S. G.: Thiol groups of biological importance. In Advanc. Enzymol. 1951, 201-266.

Boyer, P. D.: Sulfhydryl and disulfide groups of enzymes. In The Enzymes, Vol. I. ed. P. D. Boyer, H. Lardy \& K. Myrbäck. Academic Press Inc., New York 1959, 511-588.

$D e, S . S .:$ Effect of different substances on the activity of cobra (Naja naja) haemolysin. Indian J. med. Res. 1940a, 27, 793-806.

De, S. S.: Reversible inactivation of haemolysin of cobra (Naja naja) venom. Indian J. med. Res. 1940b, 27, 807-817. 
Freeman, S.: In Bone as a Tissue. ed. K. Rodahl, J. R. Nicolson \& E. M. Brown Jr., McGraw-Hill, New York 1960, 321-322.

Henrici, A. T.: An endotoxin from Aspergillus fumigatus. J. Immunol. 1939, 36, 319-338.

Lee, I. Y., E. L. Coc \& S. Freeman: Effect of Aspergillus fumigatus endotoxin on the respiration and phosphorylation of kidney tissue. Arch. Biochem. 1965, 110, 23-31.

Rutqvist, L.: Studies on Aspergillus fumigatus; toxin production by different strains and serological comparison of the strains. Acta vet. scand. $1965,6,224-233$.

Rutqvist, L. \& P. A. Persson: Studies on Aspergillus fumigatus, experimental mycotoxicosis in mice, chicks and pigs with the appearance, in pigs, of perirenal edema. Acta vet. scand. 1966, 7, $21-34$.

Shwachman, H., L. Hellerman \& B. Cohen: On the reversible inactivation of pneumococcal hemolysin. J. biol. Chem. 1934, 107, $257-265$.

Tilden, E. B., E. H. Hatton, S. Freeman, W. M. Williamson \& V. L. Koenig: Preparation and properties of the endotoxins of Aspergillus fumigatus and Aspergillus flavus. Mycopathologia (Den Haag) 1961, 14, 325-346.

Tilden, E. B., S. Freeman \& L. Lombard: Further studies of the Aspergillus endotoxins. Mycopathologia (Den Haag) 1963, 20, 254271.

Wynston, L. K. \& E. B. Tilden: Chromatographic fractionation of Aspergillus endotoxins. Mycopathologia (Den Haag) 1963, 20, $272-283$.

\section{SUMMARY}

The haemolysin and toxin in mycelial filtrates of Aspergillus fumigatus showed a distinct difference in stability when the filtrate

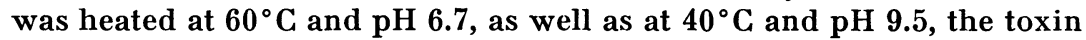
being more stable. When the filtrate was heated at $40^{\circ} \mathrm{C}$ and $\mathrm{pH} 2.5$, a rapid inactivation of both haemolysin and toxin occurred.

No haemolytic or toxic activity could be demonstrated in a filtrate with a $6 \times 10^{-2} \mathrm{M}$ concentration of formalin after incubation at $37^{\circ} \mathrm{C}$ for 3 and 4 days, respectively. Serum prepared with formalintreated filtrate as antigen had a haemolysin- and toxin-neutralizing effect.

When mercury chloride or p-chloromercuribenzoate in a final concentration of $10^{-3} \mathrm{M}$ was added to the filtrate, immediate blocking of the haemolytic activity, but not of the toxic, was obtained.

Haemolysin inactivated by mercury in a final concentration of $10^{-3} \mathrm{M}$ was reactivated under the influence of L-cysteine or glutathione in a final concentration of $10^{-2} \mathrm{M}$. 


\section{ZUSAMMENFASSUNG}

Studien über Aspergillus fumigatus; Hämolysin und Toxin - ihre Stabilität in Rohfiltrat.

In Myzelienfiltraten von Aspergillus fumigatus zeigten Hämolysin und Toxin deutlich voneinander abweichende Thermostabilität. Das Toxin erwies sich stabiler als das Hämolysin, falls Filtrate mit pH 6.7 auf $60^{\circ} \mathrm{C}$ oder mit $\mathrm{pH} 9.5$ auf $40^{\circ} \mathrm{C}$ erhitzt wurden.

Durch Erhitzung von Filtraten mit pH 2.5 auf $40^{\circ} \mathrm{C}$ wurden das Hämolysin und das Toxin schnell inaktiviert.

Nach 3-4-tägiger Wärmebehandlung von $6 \times 10^{-2} \mathrm{M}$ Formalin enthaltenden Filtraten bei $37^{\circ} \mathrm{C}$ konnte weder hämolytische noch toxische Aktivität nachgewiesen werden. Serum, hergestellt mit durch Formalin inaktiviertem Filtrat, neutralisierte das Hämolysin und das Toxin.

Eine unmittelbare Blockierung der hämolytischen Aktivität der Filtrate wurde durch den Zusatz von Quecksilberchlorid oder p-Chlormerkuribenzoat in einer Endkonzentration von $10^{-3} \mathrm{M}$ erreicht. Die toxische Aktivität wurde dadurch nicht beeinflusst. Durch Zusatz von L-Zystein oder Glutathion in der Endkonzentration von $10^{-2} \mathrm{M}$ wurde das Hämolysin vollständig reaktiviert.

\section{SAMMANFATTNING}

Studier av Aspergillus fumigatus; stabilitet hos hämolysin och toxin $i$ råfiltrat.

Hämolysin och toxin i myceliefiltrat från Aspergillus fumigatus visade tydligt divergerande stabilitet när filtratet upphettades vid $60^{\circ} \mathrm{C}, \mathrm{pH} 6.7$ och vid $40^{\circ} \mathrm{C}, \mathrm{pH} 9.5$ varvid toxinet visade bättre stabilitet än hämolysinet. När filtratet upphettades vid $40^{\circ} \mathrm{C}, \mathrm{pH} 2.5$, påvisades en snabb inaktivering av hämolysin och toxin.

Efter inkubering $i 37^{\circ} \mathrm{C}$ under tre respektive fyra dygn kunde $i$ filtrat med $6 \times 10^{-2} \mathrm{M}$ koncentration av formalin, hämolytisk resp. toxisk aktivitet icke påvisas. Serum framställt med formalinbehandlat filtrat som antigen hade hämolysin- och toxinneutraliserande verkan.

Omedelbar blockering av den hämolytiska men ej den toxiska aktiviteten erhölls när kvicksilverklorid eller p-klormerkuribenzoat i $10^{-3} \mathrm{M}$ slutkoncentration sattes till filtratet.

Av kvicksilver i $10^{-3} \mathrm{M}$ slutkoncentration inaktiverat hämolysin reaktiverades fullständigt under inverkan av L-cystein eller glutation i $10^{-2} \mathrm{M}$ slutkoncentration.

(Received May 25, 1968). 